CIVICS EDUCATION AND SOCIAL SCIENSE JOURNAL(CESSJ)

Volume 2 Nomor 1 Bulan Juni 2020

\title{
MENINGKATKAN KEMAMPUAN MENGAJUKAN PENDAPAT DALAM PEMBELAJARAN KEWARGANEGARAAN MATERI PERLINDUNGAN DAN PENEGAKAN HAM MELALUI PENGGUNAAN METODE DISKUSI BAGI SISWA KELAS VII SMPN 24 SURAKARTA SEMESTER II TAHUN PELAJARAN 2013/2014
}

\author{
Penulis \\ Tri Agustini \\ Guru PPKN SMP Negeri 24 Surakarta \\ Email: triagustini@yahoo.com
}

\begin{abstract}
ABSTRAK
Tujuan dari penelitian ini membina anak didik agar suka mendengarkan pendapat orang lain sekalipun berbeda dengan pendapat sendiri, membiasakan bersikap toleran. Subjek penelitian adalah siswa kelas tujuh A berjumlah 32 siswa, bertempat di SMP Negeri 24 surakarta pada semester dua tahun 2014 (selama 6 bulan ). Penelitian ini dilakukan dengan menggunakan netode penelitian tindakan kelas yang terdiri dari dua siklus. Siklus pertama diskusi dalam kelompok besar dan siklus kedua diskusi dalam kelompok kecil. Langkah-langkah dalam setiap siklus terdiri dari perencanaan (planning), pelaksanaan tindakan (acting), pengamatan (observing) dan refleksi (reflecting). Teknik pengumpulan data melalui observasi dengan menggunakan alat skala penilaian (checklist) untuk mengamati proses diskusi tentang kemampuan siswa dalam berpendapat dan juga menggunakan angket untuk mengetahui tanggapan siswa terhadap penggunaan metode diskusi.Cara menganalisa data menggunakan analisis diskriptif kualitatif berdasarkan hasil observasi dan refleksi.Hasil yang diperoleh membuktikan bahwa dengan berdiskusi baik dalam kelompok kecil maupun dalam diskusi kelompok besar dalam pembelajaran Kewarganegaraan terjadi kenaikan kemampuan dalam berpendapat. Kondisi awal siswa aktif dalam berpendapat +4 siswa dari 32 siswa atau $12,5 \%$. Pada siklus pertama siswa yang aktif menjadi 15 siswa atau 46,88\%, terjadi kenaikan $34,38 \%$. Dan siklus dua siswa yang aktif menjadi 21 siswa atau $65.63 \%$, terjadi kenaikan 18,75\% dari siklus pertama. Kondisi awal dibandingkan dengan siklus dua terjadi kenaikan sebesar 53,13\%.
\end{abstract}

Kata kunci : kemampuan mengajukan pendapat, metode diskusi

JORNAL PROGDI PPKn, FKIP UNIVET BANTARA SUKOHARJO BEKERJA SAMA DENGAN ASSOSIASI PROFESI PENDIDIKAN PANCASILA DAN KEWARGANEGARAAN (AP3KNI) JAWA TENGAH 
CIVICS EDUCATION AND SOCIAL SCIENSE JOURNAL(CESSJ)

Volume 2 Nomor 1 Bulan Juni 2020

\title{
IMPROVING THE ABILITY TO SUBMIT OPINION IN LEARNING CITIZENSHIP IN PROTECTION AND HUMAN RIGHTS ENFORCEMENT THROUGH THE USE OF DISCUSSION METHODS FOR STUDENTS OF CLASS VII OF SMPN 24 SURAKARTA SEMESTER II YEAR 2013/2014 ACADEMIC YEAR
}

\author{
Author \\ Tri Agustini \\ PPKn Teacher For SMP 24 Surakarta \\ Email: triagustini@yahoo.com
}

\begin{abstract}
The purpose of this research is to educate students to like to listen to the opinions of others even if they are different from their own opinions, to be tolerant. The subjects of the study were the seventh grade A students totaling 32 students, located at SMP Negeri 24 Surakarta in the second semester of 2014 (for 6 months). This research was conducted using a class action research net consisting of two cycles. The first cycle of discussion in large groups and the second cycle of discussion in small groups. The steps in each cycle consist of planning, acting, observing and reflecting. Data collection techniques through observation by using a scale tool (checklist) to observe the discussion process about the ability of students to argue and also use a questionnaire to determine student responses to the use of discussion methods. How to analyze data using qualitative descriptive analysis based on observations and reflections. The results obtained prove that by discussing both in small groups and in large group discussions in Citizenship learning there is an increase in the ability to express opinions. Initial conditions active students in the opinion + 4 students from 32 students or $12.5 \%$. In the first cycle students who were active became 15 students or $46.88 \%$, an increase of $34.38 \%$. And the cycle of two active students became 21 students or $65.63 \%$, an increase of $18.75 \%$ from the first cycle. The initial conditions compared to the second cycle increased by $53.13 \%$.
\end{abstract}

Keywords : the ability to submit opinions, the method of discussion 
CIVICS EDUCATION AND SOCIAL SCIENSE JOURNAL(CESSJ)

Volume 2 Nomor 1 Bulan Juni 2020

\section{PENDAHULUAN}

Kenyataan yang terjadi pada siswa kelas VII A SMP N 24 Surakarta, setiap kali berlangsungnya proses pembelajaran jumlah siswa yang aktif bertanya dan berpendapat kurang lebih 4 anak dari 32 anak atau 12,5\%, rendahnya kemampuan bertanya dan berpendapat ini sangat memprihatinkan. Sedangkan Negara kita adalah Negara demokrasi Negara demokrasi harus didukung oleh warga Negara yang demokratis pula.(Kurikulum 2006 : 1) Sikap demokratis antara lain diwujudkan dalam bentuk kemampuan untuk mengajukan pendapat dan menghargai pendapat. Kemampuan bertanya dan mengajukan pendapat sangat penting bagi siwa, sebab dengan kemampuan ini guru akan tahu sejauh mana siswa menguasai bahan ajar dan apa yang menjadi kesulitan kesulitan dalam mempelajari bahan ajar tersebut.Dengan kemampuan ini pula akan terjadi komunikasi yang lancar dalam pembelajaran.

Rendahnya kemampuan mengajukan pendapat ditunjukkan dengan kegiatan siswa yang hanya mendengarkan, mencatat penjelasan guru, megerjakan tugas yang diberikan, sehingga siswa terlihat hasilKomunikasi satu arah, tentu saja, pembelajaran seperti ini kurang menyenangkan. Pembelajaran yang baikjustru siswa yang aktif sedangkan guru sebagai fasilitator. Selain itu,kemampuan berpendapat dianggap penting, karena adanya tuntutan dari standar kurikulum mata pelajaran kewarganegaraan kelas sembilan untuk menilai perkembangan afeksi siswa minimal harus baik", dengan salah satu indikatornya adalah "siswa berani bertanya dan mengemukakan pendapat" (Prosedur Operasional Standar (POS) Ujian Nasional tahun 2013/2014).

Selama ini peneliti sering menggunakan metode ceramah. Dengan metode ini siswa tidak berkembang kemampuannya untuk berlatih berbicara mengemukakan pendapat, sebab metode ini tidak menuntut siswa untuk berbicara. Katà - kata guru dianggap yang paling penting, guru adalah otoritas penentu dalam prosespembelajaran.

Bertalian dengan kesenjangan - kesenjangan antara kenyataan dan harapan maka guru berkewajiban untuk berupaya mengeliminir kesenjangan kesenjangan tersebut. Adapaun kesenjangan yang menjadi permasalahan antara lain: peran aktif siswa dalam pembelajaran belum maksimal dan kemampuan bertanya serta mengajukan pendapat siswa masia rendah. Pembelajaran kewarganegaraan yang didesain guru monoton, tidak bervariasi, dan kurang melibatkan partisipasi siswa 
CIVICS EDUCATION AND SOCIAL SCIENSE JOURNAL(CESSJ)

Volume 2 Nomor 1 Bulan Juni 2020

untuk lebih aktif berpendapat karenametode yang sering dipakai adalah metode ceramah. Dengan kurangnya inovasi dan variasi dalam pembelajaran maka berkurang pula peran aktif siswa.Kurang aktifnya siswa dalam pembelajaran membuat siswa merasa bosan dan tertekan.

Banyak faktor yang mempengaruhi rendahnya kemampuan mengajukan pendapat, salah satu faktor yang cukup menetukan adalah guru. Selain guru, faktor lain yang juga menetukan adalah proses pembelajaran itu sendiri. Bertolak dari hal ini, maka untuk lebih meningkatkan kemampuan siswa dalam mengajukan pendapat perlu upaya dari guru untuk mendisain suatu pembelajaran yang inovatif sesuai dengan tugas dan kewenangannya. Dengan demikian pemilihan metode dan pendekatan yang tepat dan efektif dalam pembelajaran menjadi suatu keharusan yang perlu dilakukan oleh guru.

Salah satu desain pembelajaran yang inovatif untuk menggairahkan peran aktif siswa dalam mengajukan pendapat adalah mengemas pembelajaran kewarganegaraan dengan menggunakan metode diskusi yang mengharuskan mereka untuk berbicara mengemukakan pendapat baik dalam diskusi kelompok kecil maupun diskusi kelompok besar.

Berdasarkan paparan di atas maka mendorong guru untuk melakukan penelitian dengan judul:Meningkatkan Kemampuan Mengajukan Pendapat Dalam Pembelajaran Kewarganegaraan Materi Perlindungan dan Penegakan HAM melalui Penggunaan Metode Diskusi Bagi Siswa Kelas VII A SMPN 24 Surakarta Pada Semester II Tahun 2014.

\section{KAJIAN PUSTAKA}

Pendidikan kewarganegaraan pada hakekatnya adalah wahana untuk mengembangkan dan melestarikan nilai luhur dan moral yang berakar pada budaya bangsa Indonesia yang diharapkan dapat diwujudkan dalam bentuk perilaku dalam kehidupan sehari - hari siswa, baik sebagai individu maupun sebagai anggota masyarakat, warga Negara dan makhluk ciptaan Tuhan Yang Maha Esa (Kurikulum Pendidikan Dasar SLTP tahun 1994:1). Menurut Kurikulum Berbasis Kompetensi, Kewarganegaraan (Citizenship) adalah: mata pelajaran yang memfokuskan pada pembentukan diri yang beragam dari segi agama, sosio-kultural, bahasa, usia, dan suku bangsa untuk menjadi warga Negara Indonesia yang cerdas, terampil. Dan berkarakter yang diamanatkan oleh Pancasila dan UUD 1945 (Kurikulum 2004:2). 
CIVICS EDUCATION AND SOCIAL SCIENSE JOURNAL(CESSJ)

Volume 2 Nomor 1 Bulan Juni 2020

Mata pelajaran Pendidikan Kewarganegaraan juga diberi arti sebagai "mata pelajaran yang memfokuskan pada pembentukan warga Negara yang memahami dan mampu melaksanakan hak-hak dan kewajibannya untuk menjadi menjadi warga Negara Indonesia yang cerdas, terampil dan berkarakter yang diamantkan olch Pancasila dan UUD 1945" (Kurikulum Tingkat Satuan Pendidikan: 2).

Pengertian belajar menurut S. Nasution ada 3 macam yaitu: (a) Belajar adalah perubahan perubahan urat saraf. (b) Belajar adalah perubahan pengetahuan. (c) Belajar adalah perubahan kelakuan berkat pengalaman dan latihan.Menurut James O.Wittaker dalam bukunya Wasty Soemanto (1990: 98-99) menyatakan "Belajar sebagai proses di mana tingkah laku ditumbuhkan atau diubah melalui latihan atau pengalaman".

Hakikat Pembelajaran Pendidikan Kewarganegaraan diarahkan untuk peningkatan pemahaman, dan pengamalan nilai-nilai Pancasila dalm kehidupan berbangsa dan bernegara, melalui proses pengkajian dan praktek dalam kehidupan sehari-hari dengan cerdas, baik secara rasional maupun secara emosional.

Melalui Pendidikan Kewarganegaraan dikembangkan berbagai kemampuan dasar warga Negara seperti berpikir kritis, menghormati hak orang lain, menjalankan kewajiban, bertanggung jawab atas ucapan dan perbuatannya sesuai dengan agamanya.memiliki komitmen yang tinggi terhadap keputusan bersama. mengemukakan pikiran secara lisan dan tertulis. berargumentasi, dan berpartisipasi dalam kehidupan bermasyarakat ( Suplemen Kurikulum 1994:2 )

Mengajukan pendapat berarti menyampaikan buahpikiran, perkiraan, atau kesimpulan melalui berbagai wahana. (Tijan M,2005:113). Adalah kecakapan/kompetensi yang dimiliki oleh siswa dalam menyampaikan buah pikiran/kesimpulan tentang suatu hal, baik secara lisan ataupun tertulis. Pengertian metode yaitu suatu cara yang ditempuh guru dalam rangka mencapai tujuan yang ditetapkan.Atau bisa diartikan metode adalah cara yang sebaik baiknya mencapai tujuan.(Winarno Surakhmad, 1982:96).

Metode diskusi adalah satu cara penyajian bahan pelajaran di mana guru menugaskan pelajar atau kelompok kelompok pelajar melaksanakan percakapan ilmiah untuk mencari kebenaran (Mursidi, 1984:40). Metode diskusi bisa dipergunakan untuk mengadakan interaksi yang bertujuan: (1) Mempertinggi partisipasi setiap anggota secara individual. (2) Mempertinggi partisipasi kelompok secara keseluruhan.(Winarno Surakhmad, 1982:104) Dengan metode diskusi setiap 
CIVICS EDUCATION AND SOCIAL SCIENSE JOURNAL(CESSJ)

Volume 2 Nomor 1 Bulan Juni 2020

anggota/siswa baik secara individual maupun secara kelompok dituntut untuk berpartisipasi dengan jalan mengemukakan gagasan/pendapatnya.

\section{METODE}

\section{Setting Penelitian}

Penelitian ini kami lakukan di SMPN 24 Surakarta selama 6 bulan yaitu antara bulan Desember 2013 sampai dengan bulan Mei 2014. Penyusunan proposal mulai dari bulan Desember 2013, bulan Januari menyusun instrument penclitian, bulan Pebruari mengumpulkan data dengan melaksanakan tindakan kelas, bulan Maret 2014 menganalisa data, bulan April 2014 membahas hasil analisa data yang diperoleh dan laporan hasil penelitian di susun pada bulan Mei 2014.

\section{Sumber Data}

Penelitian ini menggunakan dua sumber data yaitu sumber data primer dan sekunder. Sumber data primer adalah siswa yang berperan sebagai subyek penelitian. Sedangkan sumber data sekunder yaitu diperoleh dari data hasil observasi yang dikumpulkan peneliti yang berkolaborasi dengan teman sejawat selama tindakan berlangsung

\section{Teknik dan Alat Pengumpulan Data}

Dalam penelitian ini, peneliti menggunakan dua teknik pengumpulan data yaitu teknik observasi untuk mengamati proses diskusi siswa, baik dalam diskusi kelompok besar maupun diskusi kelompok kecil, terutama tentang kemampuan siswa dalam berpendapat. Dan teknik angket dipakai untuk mengetahui tanggapan siswa terhadap metode diskusi yang diterapkan oleh guru.Sedangkan alat pengumpulan data menggunakan Blanko Observasi dalam bentuk skala penilaian tentang kemampuan mengemukakan pendapat dalam diskusi dan Blanko Angket tentang tanggapan siswa terhadap metode yang dipakai guru

\section{Validasi Data}

Karena penelitian ini berupa proses pembelajaran maka kevalidan data diperoleh dari sumber data dengan menggunakan teknik validasi triangulasi dari hasil observasi peneliti maupun teman sejawat. Adapun indikator yang dipakai dalam penelitian ini ada 3 indikator, di mana indikator ini terbagi dalam indikator 
CIVICS EDUCATION AND SOCIAL SCIENSE JOURNAL(CESSJ)

Volume 2 Nomor 1 Bulan Juni 2020

yang lebih terperinci, yaitu: (1) Intensitas/frekuensi bertanya/berpendapat. (2) Kualitas isi pendapat. (3) Sikap dalam berpendapat.

\section{Analisis Data}

Dalam menganalisis data, peneliti tidak menggunakan uji statistik tetapi menggunakan analaisis deskriptif kualitatif berdasarkan hasil observasi dan refleksi.

\section{Prosedur Penelitian}

Penelitian ini dilakukan dengan menggunakan metode penelitian tindakan kelas yang terdiri dari 2 siklus. Langkah-langkah dalam tiap siklus terdiri dari: perencanaan (Planning), pelaksanaan tindakan (Acting), pengamatan (Observing) dan refleksi (Reflecting).

Pada siklus I diskusi dilakukan dalam kelompok besar, tema diskusi telah disiapkan oleh guru. Langkah - langkah dalam siklus I adalah: (1) Perencanaan (planning) meliputi: (a) menyusun rencana pelaksanaan pembelajaran (RPP). (b) menyusun langkah-langkah diskusi. (c) Menyiapkan blangko pengamatan/observasi. (2) Pelaksanaan tindakan (acting). Proses diskusi dilaksanakan sesuai dengan rencana pelaksanaan pembelajaran (RPP) meliput: (a) Memberi penjelasan mengenai tata cara berdiskusi dan apa yang harus dilakukan siswa. (b) Membagi siswa dalam 4 kelompok, dengan ketua telah ditunjuk guru yang dianggap mampu, tiap kelompok terdiri dari 8 siswa. (c) Ketua kelompok memilih tema diskusi dengan jalan dikocok. (d) siswa berdiskusi. (e) Guru melakukan pemantauan dan bimbingan. (3) Pengamatan (observing), dilakukan dengan menggunakan blangko yang talah dipersiapkan, selama kegiatan diskusi dilakukan pengamatan tentang partisipasi aktif siswa dalam berpendapat, penggunaan bahasa, sikap dalam berpendapat serta pelaksanaan tata tertib berdiskusi. (4) Refleksi (reflecting), dilakukan untuk mengetahui sejauh mana efektifitas pelaksanaan tindakan pada siklus I, kekurangan dan kelebihan yang timbul pada pelaksanaan siklus I tersebut, dipergunakan sebagai bahan pertimbangan dalam menentukan tindakan pada siklus berikutnya.

Langkah-langkah pada siklus II prinsipnya sama dengan siklus I hanya diskusi dilakukan dalam kelompok kecil, ada 8 kelompok dengan anggota masingmasing 4 siswa. Masalah diskusi masih dalam standar kompetensi yang sama, 
CIVICS EDUCATION AND SOCIAL SCIENSE JOURNAL(CESSJ)

Volume 2 Nomor 1 Bulan Juni 2020

dengan soal yang berbeda, hasil diskusi dipresentasikan oleh ketua kelompok secara garis besar dan ditanggapi oleh guru serta disimpulkan bersama-sama.

\section{HASIL PENELITIAN DAN PEMBAHASAN}

Sebelum penelitian dilakukan, guru melaksanakan pembelajaran secara monoton. Guru menggunakan metode konvensional sehingga guru sebagai pembicara tunggal dalam pembelajaran, terjadi komunikasi satu arah, guru sebagai otoritas penentu, jarang mendapat pertanyaan, usul, saran atau pendapat dari siswa. Dilihat dari segi siswa: siswa pasif, jarang bertanya, jarang berpendapat, kegiatan siswa mendengarkan, mencatat, ada yang mau bertanya kurang lebih 12,5\% atau kurang lebih 4 siswa dari 32 siswa, keadaan kelas kurang hidup, kemampuan berpendapat siswa sangat rendah

\section{Deskripsi Hasil Siklus I \\ Perencanaan tindakan}

Tindakan pada tahap siklus I direncanakan selama 4 jam pelajaran dengan 2 kali tatap muka. Setiap tatap muka alokasi waktunya 2 jam pelajaran selama 80 menit. Setiap kali tatap muka, pembelajaran dibagi menjadi tiga tahap yaitu pendahuluan, kegiatan inti dan penutup. Alokasi untuk pendahuluan kurang lebih 10 menit. Kegiatan inti kurang lebih 60 menit dan penutup alokasinya 10 menit.

Tahap pendahuluan, guru memotivasi siswa untuk aktif dalam pembelajaran, menyampaikan tujuan pembelajaran, menyampaikan standar kompetensi yang harus dikuasai siswa, menyampaikan kegiatan yang akan dilakukan selama pembelajaran berlangsung, mengingatkan materi yang telah dipelajari sebelumnya, membagi siswa dalam kelompok besar/kecil beserta permasalahan yang harus mereka bahas dalam diskusi, dan memberitahukan aspekaspek yang akan dinilai dalam proses diskusi. Kegiatan inti yaitu kegiatan pokok yang dilakukan selama pembelajaran. Dalam setiap tatap muka pada siklus I, kegiatan intinya adalah sebagai berikut:

a. Siswa dikelompokkan menjadi 4 kelompok yang masing masing beranggotakan 8 siswa. Ketua kelompok telah ditunjuk oleh guru, sedangkan para anggota memilih sendiri ketua yang telah ditunjuk guru dengan catatan tidak boleh ada kelompok yang jumlahnya lebih atau kurang dari ketentuan yang dutetapkan. 
CIVICS EDUCATION AND SOCIAL SCIENSE JOURNAL(CESSJ)

Volume 2 Nomor 1 Bulan Juni 2020

b. Tiap kelompok menyusun posisi berhadapan dan untuk memotivasi keseriusan siswa, mereka diberi nomor dada sesuai dengan presensinya sebagai identitas.

c. Ketua kelompok memilih masalah yang telah dipersiapkan guru

d. Setiap kelompok berdiskusi dengan dipimpin oleh ketua masing- masing. Bagi siswa yang berpendapat/bertanya dipersilahkan untuk mengacungkan jari, berdiri, dan menyebutkan nomor presensinya.

e. Anggota yang lain menjawab atau berpendapat terhadap pertanyaan, usul, saran dari anggota yang lainnya.

f. Salah satu dari anggota kelompok menuliskan semua pertanyaan, pendapat, saran, usul dari anggota kelompok disertai dengan nomor presensinya untuk nanti dikumpulkan sebagai laporan hasil diskusi.

g. Guru mengadakan pengamatan jalannya diskusi dibantu teman sejawat dan mengisi blanko cek list yang telah dipersiapkan.

h. Disela diskusi, guru selalu memberi support agar siswa berperan aktif dan menjaga kelancaran diskusi.

i. Ketua kelompok mempresentasikan hasil diskusi kelompok secara garis besar.

j. Guru mengulas,menyimpulkan secara singkat hasil dan proses dalam diskusi serta menjawab maupun meluruskan permasalahan yang timbul dalam diskusi.

Penutup merupakan kegiatan yang dilakukan untuk mengakhiri kegiatan tatap muka. Kegiatan yang dilakukan pada tahap penutup antara lain melakukan refleksi pelaksanaan diskusi demi kesempurnaan pelaksanaan diskusi selanjutnya dengan bersama sama mencari kekurangan-kekurangan dalam diskusi serta mengungkap pengalaman pengalaman baru yang diperoleh dalam berdiskusi, memberikan tugas, persiapan diskusi pada pertemuan selanjutnya.

\section{Pelaksanaan Tindakan}

Tindakan yang dilakukan pada siklus I ini merupakan refleksi dari perencanaan tindakan yang telah disusun, meliputi kegiatan - kegiatan antara lain pendahuluan, kegiatan inti dan penutup seperti tertulis pada perencanaan tindakan. Setiap pelaksanaan tindakan dalam kegiatan diskusi dilakukan pengamatan/observasi. Observasi dilakukan oleh peneliti dan teman sejawat dengan mengisi blanko check list yang telah dipersiapkan. 
CIVICS EDUCATION AND SOCIAL SCIENSE JOURNAL(CESSJ)

Volume 2 Nomor 1 Bulan Juni 2020

\section{Hasil Observasi dan Refleksi}

Hasil pengamatan proses diskusi kelompok besar menunjukkan setiap kali proses diskusi berlangsung dari tahap pendahuluan, kegiatan inti sampai dengan penutup dimulai dari pertemuan pertama dan kedua, semua kelompok terjadi peningkatan semangat berdiskusi aktif dengan berbagai pertanyaan maupun pendapat yang mereka lontarkan meskipun kualitas pendapat rata-rata berbobot sedang cukup.

Data hasil observasi mengenai persentase keaktifan siswa dalam mengemukakan pendapat dalam diskusi kelompok besar sebagai berikut: pertemuan I siswa yang aktif bertanya dan berpendapat sebanyak 12 siswa dari 32 anak. Dari 12 siswa tersebut 4 siswa memiliki kemampuan berpendapat yang baik dan 8 siswa berkategori cukup, sedangkan 20 pasif. Pada pertemuan II siswa yang aktif bertanya dan berpendapat berjumlah 18 siswa. 6 siswa berkategori memiliki kemampuan berpendapat baik, 12 siswa kategori berpendapat cukup sedangkan 14 siswa yang lain pasif. Rata-rata keaktifan siswa dalam bertanya dan berpendapat dalam pertemuan I dan II sebanyak 15 siswa atau 46,88 \%. 5 siswa berpendapat dengan kategori baik atau 15,62 \%; 10 siswa berpendapat dengan kategori cukup atau $31,25 \%$, sedang yang pasif 17 siswa atau $53.13 \%$.

\section{Deskripsi Hasil Siklus II}

\section{Perencanaan Tindakan}

Tindakan pada tahap siklus II direncanakan selama 4 jam pelajaran dengan 2 kali tatap muka. Setiap tatap muka alokasi waktunya 2 jam pelajaran selama 80 menit. Setiap kali tatap muka, pembelajaran dibagi menjadi tiga tahap yaitu pendahuluan, kegiatan inti dan penutup. Alokasi untuk pendahuluan kurang lebih 10 menit. Kegiatan inti kurang lebih 60 menit dan penutup alokasinya 10 menit.

Tahap pendahuluan, kegiatan inti maupun penutup sama dengan siklus ke I hanya saja pada siklus yang ke II diskusi dilakukan dalam kelompok kecil.Ada 8 kelompok dalam diskusi siklus II ini dengan anggota masing-masing 4 siswa.

\section{Pelaksanaan Tindakan}

Tindakan yang dilakukan pada siklus II ini merupakan refleksi dari perencanaan tindakan yang telah disusun, meliputi kegiatan-kegiatan antara lain pendahuluan, kegiatan inti dan penutup seperti tertulis pada perencanaan tindakan. 
CIVICS EDUCATION AND SOCIAL SCIENSE JOURNAL(CESSJ)

Volume 2 Nomor 1 Bulan Juni 2020

Setiap pelaksanaan tindakan dalam kegiatan diskusi dilakukan pengamatan/observasi. Observasi dilakukan oleh peneliti dan teman sejawat dengan mengisi blanko check list yang telah dipersiapkan.

\section{Hasil Observasi dan Refleksi}

Hasil pengamatan proses diskusi kelompok kecil menunjukkan siswa yang aktif tiap-tiap kelompok antara 2 sampai 4 orang dengan kualitas pendapat yang lebih baik dan yang aktif juga lebih banyak. Untuk penggunaan bahasa rata - rata baik, lancar dalam berbicara, jelas dan bisa didengar. Untuk sikap rata rata juga sopan, tidak emosi, serius, patuh pada peraturan diskusi yang ditetapkan, hanya intensitas berbicara perlu ditingkatkan lagi.

Data hasil observasi mengenai presentasi keaktifan siswa mengemukakan pendapat dalam diskusi kelompok kecil selama 2 kali pertemuan sebagai berikut: pertemuan 1 siswa yang aktif bertanya dan berpendapat sebanyak 18 siswa. Dari 18 siswa tersebut 10 siswa kemampuan berpendapatnya baik dan 8 siswa berkategori cukup, sedangkan 14 siswa pasif. Pada pertemuan yang ke-2, siswa yang aktif bertanya dan berpendapat 24 siswa, 14 siswa kategori pendapatnya baik, 10 siswa kategori pendapatnya cukup, sedangkan 8 siswa pasif. Rata-rata keaktifan siswa dalam bertanya dan berpendapat dalam pertemuan 1 dan 2 pada siklus II yaitu 21 siswa atau 65,63 \%, 12 siswa berpendapat dengan kategori baik atau 37,5\%; 9 siswa berpendapat dengan kategori cukup atau $28,13 \%$. sedangkan yang pasif 11 siswa atau $34,38 \%$.

Dengan hasil tersebut di atas menunjukkan peningkatan kemampuan siswa dalam berpendapat yaitu pada kondisi awal kemampuan berpendapat 12,5\% menjadi 46,88 \%, pada siklus I; sedang pada siklus II meningkat menjadi 65,63\%. Berarti ada kenaikan dari kondisi awal dibanding siklus I 34,38 \%; dari siklus I dibanding siklus II naik 18,75\%; kondisi awal dibanding kondisi akhir naik 53,13 $\%$. Kenaikan ini sangat baik karena guru selalu memotivasi siswa untuk aktif berpartisipasi dalam diskusi, adanya motivasi dari nomor dada yang mereka kenakan, sehingga mereka cenderung serius untuk berharap memperoleh penilaian yang baik dan karena pada siklus II, diskusi dilaksanakan dalam kelompok kecil di mana secara psikologis mereka lebih berani untuk aktif dalam kelompoknya. 
CIVICS EDUCATION AND SOCIAL SCIENSE JOURNAL(CESSJ)

Volume 2 Nomor 1 Bulan Juni 2020

\section{KESIMPULAN}

Berdasarkan uraian hasil penelitian di atas dapat disimpulkan bahwa (1) melalui penggunaan metode diskusi dapat meningkatkan kemampuan mengajukan pendapat dalam pembelajaran kewarganegaraan bagi siswa kelas VIIA SMPN 24 Surakarta pada semester II tahun 2014. (2) Dengan penggunaan metode diskusi dapat meningkatkan partisipasi siswa dalam pembelajaran.

\section{DAFTAR PUSTAKA}

Mursidi, 1984. Didaktik Dasar dasar Belajar Mengajar. Sukoharjo: IKIP Veteran.

Roestiyah, 1998. Didaktik Metodik. Jakarta : Bumi Aksara.

The Liang Gie, 1995. Cara Belajar yang Efisien. Yogyakarta : Liberty.

Tabrani Rusyan, 1994. Pendekatan Dalam Proses Belajar Mengajar. Bandung : Remaja Rosdakarya

Tijan M, 2005. Kewargan egaraan.Jakarta : PT Gelora Aksara Pratama.

Winarno Surakhmad, 1982. Pengantar Interaksi Mengajar-Belajar.Bandung : Tarsito

, Undang-Undang RI Nomor 9 Tahun 1998 tentang Kemerdekaan Menyampaikan Pendapat. Jakarta : Sinar Grafika.

, 1994. Kurikulum Pendidikan Dasar SLTP Mata Pelajaran PKn. Jakarta : Depdikbud.

, 2004. Kurikulum Berbasis Kompetensi Kewarganegaraan. Jakarta : depdiknas.

, 2012. Kurikulum Tingkat Satuan Pendidikan Kewarganegaraan. Jakarta : Depdiknas. 